\title{
UBE2N wt Allele
}

National Cancer Institute

\section{Source}

National Cancer Institute. UBE2N wt Allele. NCI Thesaurus. Code C119647.

Human UBE2N wild-type allele is located in the vicinity of $12 \mathrm{q} 22$ and is approximately 37 $\mathrm{kb}$ in length. This allele, which encodes ubiquitin-conjug ating enzyme E2 N protein, is involved in polyubiquitination of target proteins and may play a role in transcriptional regulation. 